This is a self-archived version of an original article. This version may differ from the original in pagination and typographic details.

Author(s): Alsila, Terhi; Elo, Merja; Hakkari, Tomi; Kotiaho, Janne S.

Title: Effects of habitat restoration on peatland bird communities

Year: 2021

Version: Accepted version (Final draft)

Copyright: (c) 2020 Wiley-Blackwell

Rights: In Copyright

Rights url: http://rightsstatements.org/page//nC/1.0/?language=en

Please cite the original version:

Alsila, T., Elo, M., Hakkari, T., \& Kotiaho, J. S. (2021). Effects of habitat restoration on peatland bird communities. Restoration Ecology, 29(1), Article e13304.

https://doi.org/10.1111/rec.13304 


\section{EFFECTS OF HABITAT RESTORATION ON PEATLAND BIRD COMMUNITIES}

Running head: Effects of restoration on peatland birds

Terhi Alsila (terhi.s.alsila@gmail.com) ${ }^{1}$, MerjaElo (merja.t.elo@jyu.fi) ${ }^{1,2}$, Tomi Hakkari ${ }^{3}$ \& Janne S. Kotiaho ${ }^{1,2}$

${ }^{1}$ University of Jyväskylä, Department of Biological and Environmental Sciences, P.O. Box 35, FI-40014

University of Jyväskylä, Finland.

${ }^{2}$ University of Jyväskylä, School of Resource Wisdom, P.O. Box 35, FI-40014 University of Jyväskylä, Finland.

${ }^{3}$ Centre for Economic Development, Transport and the Environment for Central Finland (ELY Centre for

Central Finland), P.O. Box 250, Fl-40101, Jyväskylä, Finland.

Corresponding authors: terhi.s.alsila@gmail.com \&merja.t.elo@jyu.fi

Author contributions: JSK, TH designed the study; TH, TA gathered the data; ME, TA analyzed the data; TA wrote the first draft of the; ME, JSK, TH contributed substantially to the writing.

This article has been accepted for publication and undergone full peer review but has not been through the copyediting, typesetting, pagination and proofreading process which may lead to differences between this version and the Version of Record. Please cite this article as doi: $10.1111 /$ rec. 13304 


\section{ABSTRACT}

Restoration of damaged ecosystems has become an important tool to slow down the biodiversity lossand to maintain ecosystem services. Peatland bird populations have shown a substantial decline during the recent decades in Northern Europe as a consequence of peatland drainage. We studied whether restoration of peatlands drained for forestry affects bird communities. We conducted bird surveys at 11 peatlands in Western Finland, where each of the restored and their pristine counterparts were surveyed before restoration and yearly after restoration during 2010-2018. We used linear mixed effect models to analyze whether restoration affected the number of species and territories of peatland special ist and non-specialist species and permutational multivariate analysis of variance to analyze the change in community composition. Drained parts of the peatlands had higher number of territories of non-specialist species before restoration, and restoration seemed to decrease these numbers towards the level of pristine parts. By contrast, restoration did not affect the number of peatland special ists and their territories, which was lower in drained than in pristine parts of the peatlands. Bird communities in restored parts remained different from pristine parts in terms of community composition after restoration. Thus, despite the effect of restoration on nonspecialists, a substantially long time may be required for a recovery of the peatland bird communities. Based on our results, it seems that long term monitoring of the restored and pristine peatlands is needed to determine whether restoration is effective in recovering the peatland specialist bird species and bird communities in general.

Key words: biodiversity, community ecology, conservation, disturbance, draining, mire birds

\section{Implications}


- Ecological restoration of peatlands decreased the abundance of non-specialist bird species and tended to halt the decline of peatland specialist species, which is a general trend in pristine peatlands. However, these effects were not very strong.

- The general bird community composition still differed between pristine and restored peatlands at the end of the study period, implying that the full recovery of the peatland bird community is uncertain and will take a substantially long time.

- Pristine peatlands are essential habitats for peatland specialist bird populations and a source of colonization for restored peatlands.

- To halt the decline of the peatland specialist species, maintaining pristine areas undisturbed and initiating ecological restoration of the degraded peatlands as soon as possible is needed. 


\section{INTRODUCTION}

Globally, less than a quarter of the land area remains free from significant anthropogenic impact (IPBES 2018). Climate change and land-use change, coupled with other anthropogenic disturbances, have led to declines in population sizes as well as species extinctions, with consequent effects on ecosystem functioning (Butchart et al. 2010; Barnosky et al. 2011; Cardinale et al. 2012). Ecological restoration, defined as an intentional activity that initiates or accelerates the recovery of an ecosystem (SER 2004; Gann et al. 2019), has a potential to slow down the biodiversity loss and maintain ecosystem services (Hobbs \& Harris 2001; Hobbs \& Cramer 2008; Bullock et al. 2011). Under the Convention on Biological Diversity (CBD), the governments of the global society have agreed to restore $15 \%$ of the degraded ecosystems by 2020 (UNEP, CBD \& COP 2010). It is clear that this target is not going to be met, and therefore, United Nations General Assembly (UNGA) declared the decade 2021-2030 as the decade of ecosystem restoration(UNGA 2019). The aim of this resolution is to scale up the ecological restoration of degraded and destroyed ecosystems as a proven measure to fight the climate crisis and enhance biodiversity.

One of the most degraded habitat types are wetlands and peatlands of which over $70 \%$ have been destroyed during the last 300 years (IPBES 2018). Peatlands alone cover 4 million $\mathrm{km}^{2}$ (3\%) of the world's land area (Parish et al. 2008; Erwin 2009). In their natural state, they play an important role in global carbon cycle (Yu et al. 2011; Andersen et al. 2017) and have a unique species composition, thus being of high value to biodiversity (Littlewood et al. 2010; Minayeva et al. 2017). The greatest factors responsible for peatland degradation have been drainage for forestry and transformation to agricultural lands (Joosten \& Clarke 2002). 
The natural pristine state of the peatlands, together with hydrology and carbon storing capacity, recover faster trough restoration (Jauhiainen et al. 2002; Vasander et al. 2003; Haapalehto et al. 2014). However, recovery may be incomplete and in many aspects the restored peatlands may differ greatly from their pristine state (Moreno-Mateos et al. 2012; Haapalehto et al. 2017). Indeed, a full recovery of peatland biota may take several decades (Gorham \& Rochefort 2003; Moreno-Mateos et al. 2012), even though a significant number of typical peatland species can recover in 3-5 years (Gorham \& Rochefort 2003; Noreika et al. 2015). Ecosystem functioning such as carbon sequestration may recover faster than the characteristic species composition (Kareksela et al. 2015). Several peatland bird populations have declined during recent decades in Europe (Hancock et al. 2009; Fraixedas et al. 2017; Lehikoinen et al. 2019). In Finland, the decline of peatland bird populations has been particularly severe (Fraixedas et al. 2017), and currently 58\% of bird species using primarily peatlands for breeding are on the Red List (Lehikoinen et al. 2019). This is likely to reflect the fact that in Finland $60 \%$ of peatlands have been drained for agriculture and forestry (Aapala et al. 2013; Kaakinen et al. 2018). The major effect of drainage is a water level drawdown by 20-60 cm (Laine \& Vanha-Majamaa 1992; Haapalehto et al. 2011). This causes significant changes in hydrology, acidity, and nutrient gradients (Holden 2005) which in turn change peatland vegetation (Eloet al. 2016). Restoration aims to reverse these changes by filling inand blocking the ditches as well as cutting the trees grown after drainage (Penttinen 2015). In Finland, the area of restored peatlands was approximately 32400 hectares by the end of the year 2017 (Kaakinen et al. 2019).

There is a paucity of studies on the effect of peatland restoration on birds as most of the studies concentrating on the effect of peatland restoration have focused on vascular plants and bryophytes (Tahvanainen et al. 2002; Rochefort et al. 2003; Lucchese et al. 2010; Haapalehto et al. 2011; Wortley et al. 2013; Andersen et al. 2017). In addition, the ecological requirements of peatland bird species are 
understudied (Newey et al. 2016; Fraixedas et al. 2017), hindering our ability to predict their response to restoration. However, peatland specialist species seem to prefer openness and wetness (Järvinen \& Sammalisto 1976; Väisänen et al. 1998; Fraixedas et al. 2017), and have lower preferences for ditched peatlands (Väisänen \& Rauhala 1983; Fraixedas et al. 2017). Thus, we expect that peatland special ist species are likely to benefit from ecological restoration. Indeed, some peatland bird monitoring programs have shown a positive effect of restoration after lessthan 10 years (Brown \& Batzer 2001). For example, in United Kingdom Golden Plover (Pluvialias a pricaria) was shown to benefit from peatland restoration in three years. The success was attributed to the increased the abundance of crane flies, an important food source for the species, caused by the recovered higher water levels (Pearce-Higgins 2010; Carroll et al. 2011; Pearce-Higgins 2011).

A substantial part of the European peatland birds migrates to Finland to breed (Tiainen et al. 2010), and relative to the area, Finland has the highest share of peatlands in the world (Lappalainen 1996; Vasander et al. 2003). Therefore, Finland has a high responsibility in international peatland bird conservation (Tiainen et al. 2010, Lehikoinen et al. 2019). The aim of this study is to determine whether ecological restoration as commonly implemented on forestry drained peatlands in Finland has an overall effect on recovery of the bird communities. In a longitudinal monitoring study, we analyze the bird communities, numbers of bird territories and number of species before and after restoration in comparison to pristine counterparts. We hypothesized that by increasing the openness and wetness of the peatlands, restoration increases the number of peatland specialist species and their territories, decreases the number of non-specialist species and their territories, and thus results in changes in bird community composition.

\section{METHODS}




\section{Study set-up}

The study was conducted on 11 peatlands located in Western Finland (Table 1, Fig. 1), and it was part of the Boreal Peatland LIFE project 2010-2014. The aim of the restoration was mainly to improve the ecological quality and recreational value of Natura 2000 priority peatland habitats such as Aapa mires, Bog woodlands and Active raised bogs (Penttinen 2015). The 11 peatlands selected for the study were originally either pine dominated or treeless mires (referred commonly as peatlands), which were partially ditched to initiate draining and facilitate tree growth during the 1960s and 1970s. Each of the peatlands included a treatment part that was initially drained and subsequently restored during the LIFE project, and a pristine counterpart that was used as a control (see Fig. 2). The area of the treatment part varied between 4.7 and $23.3 \mathrm{ha}$, and a control part of identical shape and size was established in the pristine counterpart. Control parts were always close to their treatment parts to reduce the differences in abiotic and biotic factors affecting the site. This design was also taken into account when analyzing the data (see Statisticalanalyses). The distance between the treatment and control parts ranged from 0.39 to $2.36 \mathrm{~km}$, being on average $1.06 \mathrm{~km}$.

We sampled the birds before restoration in the year 2010. One treatment part was restored al ready in 2005 and was thus not sampled before restoration (Table 1). The rest of the treatment parts were restored during the years 2010-2012. Since the peatlands included in the study were ditched for forestry resulting in decreased water levels and sometimes enhanced treegrowth (Laine \& Vanha-Majamaa 1992; Haapalehto et al. 2011), the restoration actions aimed to reverse these effects. Thus, restoration was conducted by filling in the existing ditches with peat, and constructing dams to raise water levels. In cases where drainage had increased tree growth open habitats where created by cutting the trees with a chain saw and removingthem. 
Tree removal is a significant restoration act aside of rising water levels influencing systematically the vegetation structure of the restored peatlands and peat formation. After restoration, we repeated the censuses yearly in each of the treatment and control parts during the years 2011-2018. The total number of sampling years differed from one to five depending on the year when the restoration was conducted on the treatment part (Table 1). Control parts always had the same number of censuses than the treatment counterparts.

We used the territory mapping of birds as a census method (Kendeigh 1944) in both pristine and restored parts, and yearly censuses were performed during the recommended census period between $30^{\text {th }}$ May and $20^{\text {th }}$ June. We performed the censuses betweenfour and ten a.m. in dry and calm weather by walking slowly $(1.5 \mathrm{~km} / \mathrm{h})$ al ong the predefined 50-meter wide transect, which covered most of the censusarea, usinga map and GPS. All the observed territories of birds in transects were marked on the map. We considered 1) a seen or heard male, 2) a pair, 3) a lonely female, 4) a brood or 5) a nest as a territory. We classified all the observed bird species in two classes. Peatland specialist species were classified after Rajasärkkä (2013) accompanied by two species, E. rustica and E. schoeniclus, after Fraixedas et al. (2017). The rest of the species were considered as species not specialized on peatlands (non-specialist species). Some of the species classified here as peatland specialists also inhabit other open habitats (e.g., waterfront meadow and arable land). However, the Finnish populations nest primarily on open or pine dominated peatland habitats (FinBIF 2020). Therefore, we followed the Finnish classification by Rajasärkkä (2013) and Fraixedas et al. (2017).

\section{Statistical analyses}


First, we analyzed whether restoration had an effect on 1) species richness of all birds, 2) species richness of peatland special ist species, 3) species richness of non-specialist species, 4) number of territories of all birds, 5) number of territories of peatland specialist birds, and 6) number of territories of non-specialist species. We used linear mixed models and entered sampling area, treatment ('Treat', where " 0 " refers to pristine and " 1 " to restored parts), sampling year, years since restoration and the interactions between treatment and sampling year, and treatment and year since restoration as fixed factors. We added the study site as a random factor to control for the site-specific differences in bird community compositions, as the control and treatment parts were located near to each other. We developed a complete set of models including all explanatory variable combinations for the six different response variables, separately. Because years since restoration and sampling year were highly correlated $(r=0.85)$, we restricted the model set not to contain these variables in the same model. To enhance the normality and homoscedasticity of the model residuals we $\log _{10}$-transformed the response variables and sampling area. In addition, we centered to zero and scaled sampling year and year since restoration. We used Akaike Information Criterion for small samplesizes (AICC) to compare the models within a set. The model with the smallest AICc is considered the best with respect to expected Kullback-Leibler information lost (Burnham \& Anderson 2002).

As the best model in the set was not always apparent, we calculated the relative importance (I) of each variable using the models for which $d_{i}<5$, where $d_{i}=\mathrm{AICc_{ \textrm {i } }}-\mathrm{AICC_{ \text {min } }}$ is the Akaike distance $d$ of each model $i$ (Burnham \& Anderson 2002). / is a sum of Akaike weights over all of the models in which the variable appears, and it ranges from zero (not important) to one (highly important). We also calculated model-averaged parameter estimates and their standard errors from the models with $d_{i}<5$. Further, we ensured that there was no spatial autocorrelation in the residuals of the best models with Moran's I statistic. 
Second, we analyzed whether restoration had an effect on the bird community composition. For this analysis, we used only the sampling years 2010 (before the restoration) and 2018. The site where the treatment part was restored already in 2005 was excluded from the analysis resulting in $n=10$. We calculated two dissimilarity indices: occupancy-based Sørensen's index and abundance-based Bray-Curtis index (Magurran 2004). We used permutational multivariate analysis of variance (PERMANOVA) which is a nonparametric test relying on permutations and can be based on any dissimilarity measure (Anderson 2001). The test is sensitive to differences in the dispersion of sites, even though the locations (i.e., mean community composition) do not differ (Anderson 2001). Thus, to infer whether community dispersions vary among the four groups (pristine 2010, before restoration 2010, pristine 2018, after restoration 2018) we used the distance-based test for homogeneity of multivariate dispersions (Anderson 2006). It is essentially a multivariate extension of Levene's test of homogeneity or variances and can be based on any distance or dissimilarity measure. The procedure counts the distance of each part to the multivariate centroid of the group, and statistical significance is tested by permutation of residuals (999 permutations) (Anderson 2006). PERMANOVA analyses were done in R (version 3.5.1, R Development Team 2017) with 'adonis2' functionand multivariate dispersion with 'betadisper' function in the "vegan" package (Oksanen et al. 2013). We also used packages "nlme" (Pinheiro et al. 2019) to analyze linear mixed models for the number of species and number of territories for all birds, peatland specialist species, and non-specialists, and “MuMIn" (Barton 2019) for model selection.

The average temperature during the last sampling spring $\left(13.7^{\circ} \mathrm{C}\right)$ in Central Finland (May 2018) was $4-5^{\circ} \mathrm{C}$ warmer than the long-term average (IImatieteenlaitos 2019a) which may affect the activity of the birds (Slagsvold 1977). However, since our sampling scheme was paired, and restored and pristine parts were sampled within a short time period (six hours), it is likely that the activity of the birds is similar in both parts and this should not bias our results. 


\section{RESULTS}

During the study period, we observed 62 bird species and 1166 territories (Table S1). Sixteen species were classified as peatland specialists and they had altogether 382 territories (Table S1).

\section{Number of all species and their territories}

The total number of bird species and the number of their territories was higher in restored than in pristine parts before restoration and throughout the study period (Table S2, Fig. 3a,d). The models gave only little support for the effect of restoration on the number of species or territories of all bird species (Tables S2 \& S3). By contrast, the larger the area, the higher the number of both species and territories (Tables S2 \& S3). The number of territories became smaller throughout the years, irrespective of whether the part was restored or pristine (Table S2, Fig. 3d).

\section{Number of peatland specialist species and their territories}

The number of peatland specialist species and their territories was higher in pristine than in restored parts before restoration, but the difference seems to become smaller during the years (Table S2, Fig. 3b,e). However, there was only little support for the effect of restoration on the number of peatland specialist species or the number of their territories (Tables S2 \& S3). The best models for the number of peatland specialist species and their territories explained $5 \%$ and $6 \%$ of the variation, respectively, which is substantially smaller than the variance explained by the best model for the non-specialist species ( $54 \%$ for 
the number of species and $56 \%$ for the number of territories). It is also notable that there was support for various models, and none of the models was clearly better. Thus, the number of peatland specialist species and their territories was not very well explained by the explanatory variables used here.

\section{Number of non-specialist species and their territories}

The number of species and territories of non-specialist specialist species was higher in restored than in pristine parts before restoration and throughout the study period (Table S2, Fig. 3c,f). There was support for an effect of restoration on the number of both species and territories of non-specialist species as the interaction between sampling year and treatment was included in the best model (Table S3). During the years, restoration had a negative effect on the number of species and territories i.e., their numbers decreased while in pristine parts they seemed to remain as they were (Table S2, Fig. 3c, f). However, the observed decline is not particularly strong, as the importance of the variable was only 0.46 and 0.57 for the number of species and the number of territories, respectively (Table S2). In addition, the larger the area the greater both the number of species and territories (Tables S2 \& S3).

\section{Community composition}

The pristine and restored parts had different community composition, as the effect of treatment was significant with Sørensen and Bray-Curtis indices (Table S4). Furthermore, the effect of year was significant with Bray-Curtis (Table S4), indicating that there were changes in species abundances between the sampling years 2010 and 2018 (Fig. 4). By contrast, restoration, i.e., interaction between treatment and year, had no effect on the community structure in none of the dissimilarity indices (Table S4) despite the group centroids 
being somewhat closer to each other with the abundance-based Bray-Curtis metric (Fig. 4). There were no differences in the dispersion among the fourgroups formed by the two treatments and two sampling years measured with the Sørensen $\left(F_{3,36}=0.67, P=0.591\right)$ or Bray-Curtis index $\left(F_{3,36}=1.62, P=0.206\right)$.

\section{DISCUSSION}

Restoration of peatlands drained for forestry seemed to decrease the number of territories of non-specialist species during our monitoring time (6to 13 years since restoration). By contrast, restoration didnot have an effect on the number of peatland specialist bird species or the number of their territories, and restored peatlands bird communities remained different from pristine peatlands in terms of total species richness, total number of territories and community composition. These results highlight the importance of pristine peatlands for peatland specialist bird populations as current habitats, and as sources for possible future colonization of restored peatlands.

Drained parts had altogether more bird species and territories than pristine parts, both before and after restoration. This result was driven by the number of non-specialist species and their territories, and is congruent with the findings that bird diversity in peatlands may increase with disturbances (Minayeva et al. 2017). Indeed, in our study non-special ists included generalist species, such as Willow Warbler (Phylloscopus trochilus) and Chaffinch (Fringilla coelebs). These species occupy mainly forested habitats and most likely benefit from the increased tree cover in drained parts (Väisänen \& Rauhala 1983). Thus, while drainage increased abundance of non-specialist species, restoration was successful in decreasing the abundance of these species back towards their natural level. Such changes should move the whole bird community composition of restored peatlands towards the community composition of pristine peatlands, and although 
a subtle change of the restored parts towards their pristine counterparts was observed, it was not statistically significant in the formal community composition analysis.

The decrease of non-specialists was not balanced with an increase of peatland specialist species, which are the target of the peatland restoration actions. It is possible that the restored peatlands were not core areas of peatland species even before ditching in the 1960s. That being said, the pristine counterparts were chosen with great care to match the drained parts, and the drained parts did have less peatland specialists before the restoration took place. A possible reason for the lack of response from peatland specialists may be the still relatively short time frame of the study, although study sites had shown positive changes in hydrology, vegetation and peat formation during Boreal Peatland LIFE project (Penttinen 2015). We do acknowledge that many potentially important explanatory variables were not measured in our study, and differences in the original vegetation of restored parts may have caused some differences in the species community compositions. However, as already mentioned, the study was designed to reduce the potential for these differences by surveying control parts always next to treatment parts.

As we know surprisingly little about the detailed ecological requirements of the peatland specialist birds (Newey et al. 2016; Fraixedas et al. 2017), it is difficult to determine why they did not benefit more from restoration. Generally, peatland specialists seem to prefer openness and wetness (Järvinen \& Sammalisto 1976; Väisänen et al. 1998; Fraixedas et al. 2017), but it is really not well understood what exact habitat features benefit different species. Most likely, these features are species-specific and may include, for instance, food resources (e.g. Pearce-Higgins 2010; Carroll et al. 2011; Pearce-Higgins 2011). It may well be that the restoration success in terms of water level increase may vary within the study sites (Haapalehto et al. 2014). This may result in variation in other environmental features, such as vegetation and insect fauna, 
which in turn affect peatland specialist bird species. Thus, we urge future studies to measure environmental variables, such as water level, openness and vegetation structure. Incorporating these into modeling process with bird census data would help to determine how to make peatland restoration more successful for bird conservation.

However, we also note that rather than determining the detailed reasons for the community composition changes, the aim of the study was to determine whether peatland restoration as commonly implemented in Finland was effective overall in recovering the bird communities. Generally, habitat restoration can take several decades and still be incomplete (Moreno-Mateos et al. 2012; Andersen et al. 2017). Particularly in boreal peatlands, the recovery rate of peatlands is even longer than for example in tropics since ecosystem processes, e.g., water and biogeochemical cycle, in general are slower (Benayas et al. 2009). However, there are some examples of fast response to restoration. As already stated in the introduction, in United Kingdom Golden Plover benefited al ready after three years of restoration (Pearce-Higgins 2010; Carroll et al. 2011). In our data, there was no sign of an increasing number of Golden Plover territories (result not shown). Thus, despite of some examples of fast response to restoration, slower recovery rates seem to be more general. This underscores the need of longer time-series to assess the effectiveness of restoration on peatland biota.

We found that the number of territories of all species decreased during the studyperiod both in pristine and restored parts. This overall decrease of territories seems to be a combination of decline of non-specialist species in restored parts, and the general declining trend of peatland specialists in pristine parts. The declining trend for peatland specialist territories may reflect the overall situation of birds using primarily peatlands as main habitats in Finland: the abundance of several of these species has declined resulting in $58 \%$ of the species to be included in the latest Red list of Finland (Lehikoinen et al. 2019). From the 16 
peatland specialist species occurring in our study sites, six were included in the Red List (Lehikoinen et al. 2019). The causes of threat of these species included obviously peatland drainage for forestry and peat extraction but also other causes such as hunting (Bean goose, Eurasian curlew), water construction (Bean goose), changes in arable land (Eurasian curlew), climate change (Willow ptarmigan) as well as unknown reasons (Common snipe, Common greenshank). Moreover, the future threat factors include also changes in other countries (Bean goose, Common greenshank, Wood sandpiper). Indeed, many of the peatland specialists nesting in Finland are migratory, and they are prone to habitat lossin their over-wintering habitats and problems during migration (Berthold 2001; Sanderson et al. 2006). This exemplifies that peatland specialist species as a species group experience simultaneously multiple threats, which may hamper their ability to benefit from restoration actions. On the other hand, the general declining trend of the peatland specialist species was not clear in the restored peatlands, suggesting that perhaps restoration might help peatland specialist species to resist the general decline. Nevertheless, this trend was not significant and it was largely driven by a single pristine part in 2010 having very high number of peatland special ist's territories.

Several factors (e.g., habitat openness, cryptic bird species, size and secretive behavior of birds) might cause bias to detection rate of birds and sampling data (Emlen 1971; Bibby et al. 2000). However, territory mapping is an effective survey method for population estimates during the breeding season (Baillie 1991). Since surveys were performed during the time when birds are most active with displaying and singing, we expected the detectability to be high. The 2018 sampling spring was exceptionally warm and dry (IImatieteenlaitos 2019a), which could have affected the monitoring of birds and caused bias. Intra- and interspecific variation in birds singing peak, mating display and breeding (Emlen 1971; Rehm \& Baldassarre 2007) depend more on warm and sunny weather than migration timing (Slagsvold 1977; Elkins 2010; Kluen et al. 2017). Hence, birds may have started breeding before the survey time, decreasing their singing and pairing activity at the time 
of doing the survey (Koskimies \& Väisänen 1988). Moreover, previous summers 2016 and 2017 were exceptionally cold and rainy (IImatieteenlaitos 2019b; Ilmatieteenlaitos 2019c). This may have had negative effects on birds breeding success in Finland, since breeding success is known to decrease in harsh weather conditions (Whitehouse et al. 2013).

In conclusion, the study showed that restoration decreased the abundance of non-specialist bird species, and that this decline was not balanced by an increase of peatland specialist species. Moreover, the general bird community composition remained different in pristine and restored peatlands six to ten years after restoration. Therefore, the recovery of the peatland bird community may take a substantially long time if it will ever recover. This underlines the importance of maintaining the remaining pristine areas undisturbed. Moreover, given the general declining trend of peatland specialist species, our results suggest that restoration actions should be implemented sooner rather than later if the decline of peatland specialist species is aimed to be halted.

\section{ACKNOWLEDGEMENTS}

We thank the Finnish Foundation for Nature Conservation, Suomen Biologian Seura Vanamo ry, Societas pro Fauna et Flora Fennica and Keski-Suomen lintutieteellinen yhdistys ry (KSLY) for funding the project during 2018 (for TA), and Kone Foundation (for ME). We are also thankful for Metsähallitus and ELY Centre for Central Finland for collaboration as well as the people helping with data collection. 


\section{LITERATURE CITED}

Aapala K, Similä M, Penttinen J (2013) Handbook for the restoration of drained peatlands. Nature Protection Publications of Metsähallitus, Series B 188, Metsähallitus, Vantaa, Finland [in Finnish with English abstract]

Andersen R, Farrell C, Graf M, Muller F, Calvar E, Frankard P, Caporn S, Anderson P (2017) An overview of the progress and challenges of peatland restoration in Western Europe. Restoration Ecology 25:271-282

Anderson MJ (2001) A new method for non-parametric multivariate analysis of variance. Austral Ecology 26:32-46

Anderson MJ (2006) Distance-based tests for homogeneity of multivariate dispersions. Biometrics 62:245253

Baillie SR (1991) Monitoring terrestrial breeding bird populations. Monitoring for Conservation and Ecology $112-132$

Barnosky AD, Matzke N, Tomiya S, Wogan GOU, Swartz B, Quental TB, Marshall C, McGuire JL, Lindsey EL, Maguire KC, Mersey B, FerrerEA (2011) Has the Earth's sixth mass extinction already arrived? Nature 471:5157

Barton K (2019) MuMIn: Multi-Model Inference. R package version 1.43.6.

https://CRAN.R-project.org/package=MuMIn 
Benayas RJM, Newton AC, Diaz A, Bullock JM (2009) Enhancement of biodiversity and ecosystemservices by ecological restoration: A meta- analysis. Science 325:1121-1124

Berthold P (2001) Bird migration: a general survey. Oxford University Press, Oxford

Bibby C, Burgess N, Hill D, Mustoe S (2000) Bird census techniques $-2^{\text {nd }}$ Edition. Academic Press, Cambridge

Brown SC, Batzer DP (2001) Birds, plants, and macroinvertebrates as indicators of restoration success in New York marshes. Pages 237-248 In: Rader RB, Batzer DP, Wissinger SA (eds), Bioassessment and management of North American freshwater wetlands. John Willey \& Sons, New York

Bullock JM, Aronson J, Newton AC, Pywell RF, Rey-Benayas J (2011) Restoration of ecosystem services and biodiversity: conflicts and opportunities. Trends in Ecology \& Evolution 26:541-549

Burnham KP, Anderson DR (2002) Model selection and multimodel inference. A practical informationtheoretic approach. Springer Science + Business Media LLC, London

Butchart SH, Walpole M, Collen B, Van Strien A, Scharlemann JPW, Almond REA, Baillie JEM, Bomhard B, Brown C, Bruno J, Carpenter KE, Carr GM, Chanson J, Chenery AM, Csirke J, Davidson ND, Dentener F, Foster M, Galli A, Galloway JN, Genovesi P, Gregory RD, Hockings M, Kapos V, Lamarque J, Leverington F, Loh J, McGeoch MA, McRae L, Minasyan A, Morcillo MH, Oldfield TEE, Pauly D, Quader S, Revenga C, Sauer JR, 
Skolnik B, Spear D, Stanwell-Smith D, Stuart SN, Symes A, Tierney M, Tyrrell TD, Vié J, Watson R (2010) Global biodiversity: indicators of recent declines. Science 328:1164-1168

Cardinale BJ, Duffy JE, Gonzalez A, Hooper DU, Perrings C, Venail P, Narwani A, Mace GM, Tilman D, Wardle DA, Kinzing AP, Daily GC, Loreau M, Grace JB, Larigauderie A, Srivastava DS, Naeem S (2012) Biodiversity loss and its impact on humanity. Nature 486:59-67

Carroll MJ, Dennis P, Pearce-Higgins JW, Thomas CD (2011) Maintaining northern peatland ecosystems in a changing climate: effects of soil moisture, drainage and drain blocking on craneflies. Global Change Biology 17:2991-3001

Debinski DM, Holt RD (2001) Review : A survey and overview of habitat fragmentation experiments. Conservation Biology 14:342-355

Elkins N (2010) Weather and bird behavior. T \& A D Poyser, Lontoo

Elo M, Kareksela S, Haapalehto T, Vuori H, Aapala K, Kotiaho JS (2016) The mechanistic basis of changes in community assembly in relation to anthropogenic disturbance and productivity. Ecosphere 7:1-12

Emlen JT (1971) Population densities of birds derived from transect counts. The American Ornithological Society $88: 323-342$ 
Erwin KL (2009) Wetlands and global climate change: the role of wetland restoration in a changing world.

Wetlands Ecology and Management 17:71-84

Finnish Biodiversity Information Facility (FinBIF) (2020). LAJI.FI

https://laji.fi (accessed 6.2.2020)

Fraixedas S, Lindén A, Lehikoinen A (2015) Population trends of common breeding forest birds in southern Finland are consistent with trends in forest management and climate change. Ornis Fennica 92:187-203

Fraixedas S, Lindén A, Meller K, Lindström Å, Keišs O, Kålås JA, Husby M, Leivits A, Leivits M, Lehikoinen A (2017) Substantial decline of Northern European peatland bird populations: Consequences of drainage. Biological Conservation 214:223-232

Gann GD, McDonald T, Walder B, Aronson J, Nelson CR, Jonson J, Hallett JG, Eisenberg C, Guariguata MR, Liu J, Hua F, Echeverría C, Gonzales E, Shaw N, Decleer K, Dixon KW (2019) International principles and standards for the practice of ecological restoration. Second edition. Restoration Ecology 27:1-46

Gorham E, Rochefort L (2003) Peatland restoration: A brief assessment with special reference to sphagnum bogs. Wetlands Ecology and Management 11:109-119

Haapalehto TO, Vasander H, Jauhiainen S, Tahvanainen T, Kotiaho JS (2011) The effects of peatland restoration on water-table depth, elemental concentrations, and vegetation: 10 years of changes. Restoration Ecology 19:587-598 
Haapalehto T, Juutinen R, Kareksela S, Kuitunen M, Tahvanainen T, Vuori H, Kotiaho JS (2017) Recovery of plant communities after ecological restoration of forestry-drained peatlands. Ecology and Evolution 7:78487858

Haapalehto T, Kotiaho JS, Matilainen R, Tahvanainen T (2014) The effects of long-term drainage and subsequent restoration on water table level and pore water chemistry in boreal peatlands. Journal of Hydrology 519:1493-1505

Hancock MH, Grant M, Wilson JD (2009) Associations between distance to forest and spatial and temporal variation in abundance of key peatland breeding bird species. Bird Study 56:53-64

Hobbs RJ, Cramer VA (2008) Restoration ecology: interventionist approaches for restoring and maintaining ecosystem function in the face of rapid environmental change. Annual Review of Environment and Resources 33:39-61

Hobbs RJ, Harris JA (2001) Restoration ecology: Repairing the earth's ecosystems in the new millennium. Restoration Ecology 9:239-246

Holden J (2005) Peatland hydrology and carbon release: why small-scale process matters. Philosophical Transactions of the Royal Society A: Mathematical, Physical and Engineering Sciences 363:2891-2913

Ilmatieteenlaitos (2019a) Toukokuun 2018 sää ja tilastot. 
https://ilmatieteenlaitos.fi/toukokuu (accessed 6 May 2019) [in Finnish]

Ilmatieteenlaitos (2019b) Vuoden 2016 sää

https://ilmatieteenlaitos.fi/vuosi-2016 (accessed 21 September 2019) [in Finnish]

Ilmatieteenlaitos (2019c) Vuoden 2017 sää

https://ilmatieteenlaitos.fi/vuosi-2017 (accessed 21 September 2019) [in Finnish]

IPBES (2018) Summary for policymakers of the thematic assessment report on land degradation and restoration of the Intergovernmental Science-Policy Platform on Biodiversity and Ecosystem Services. Scholes R, Montanarella L, Brainich A, Barger N, ten Brink B, Cantele M, Erasmus B, Fisher J, Gardner T, Holland TG, Kohler F, Kotiaho JS, Von Maltitz G, Nangendo G, Pandit R, Parrotta J, Potts MD, Prince S, Sankaran M, Willemen L (eds.). IPBES secretariat, Bonn, Germany

Jauhiainen S, Laiho R, Vasander H (2002) Ecohydrological and vegetational changes in a restored bog and fen. Annales Botanici Fennici 39: 185-199

Joosten H, Clarke D (2002) Wise use of mires and peatlands - Background and principles including a framework for decision-making. International Mire Conservation Group and International Peat Society

Järvinen O, Sammalisto L (1976) Regional trends in avifauna of Finnish peatland bogs. Annales Zoologici Fennici 13:31-43 
Kaakinen E, Kokko A, Aapala K, Autio O, Eurola S, Hotanen J-P, Kondelin H, Lindholm T, Nousiainen H, Rehell S, Ruuhijärvi R, Sallantaus T, Salminen P, Tahvanainen T, Tuominen S, Turunen J, Vasander H, Virtanen K (2018) Suot. Pages 117-170 In: Kontula T, Raunio A (eds) Suomen luontotyyppien uhanalaisuus 2018. Luontotyyppien punainen kirja - Osa 1: Tulokset ja arvioinnin perusteet. Suomen ympäristökeskus \& ympäristöministeriö, Helsinki, Finland [in Finnish]

Kareksela S, Haapalehto T, Juutinen R, Matilainen R, Tahvanainen T, Kotiaho JS (2015) Fighting carbon loss of degraded peatlands by jump-starting ecosystem functioning with ecological restoration. Science of The Total Environment 537:268-276

Kendeigh SC (1944) Measurement of bird populations. Ecological Monographs 14:67-106

Kluen E, Nousiainen R, Lehikoinen A (2017) Breeding phenological response to spring weather conditions in common Finnish birds: resident species respond stronger than migratory species.Journal of Avian Biology 48:611-619

Koskimies P, Väisänen RA (1988) Linnustonseurannan havainnointiohjeet. Helsingin yliopiston eläinmuseo, Helsinki, Finland [in Finnish]

Laine J, Vanha-Majamaa I (1992) Vegetation ecology along a trophic gradient on drained pine mires in southern Finland. Annales Botanici Fennici 29:213-233 
Lappalainen E(1996) Peatlands and peat resources in Finland. Pages 36-38 In: Vasander H (eds) Peatlands in Finland. Finnish Peatland Society, Helsinki, Finland

Lehikoinen A, Jukarainen A, Mikkola-Roos M, Below A, Lehtiniemi T, Pessa J, Rajasärkkä A, Rintala J, Rusanen P, Sirkiä P, Tiainen J, Valkama J (2019) Birds. Pages 560-571 In: Hyvärinen E, Juslén A, Kemppainen E, Uddström A, Liukko UM (eds) The 2019 Red List of Finnish Species. Ministry of the Environment \& Finnish Environment Institute, Helsinki, Finland [in Finnish with English abstract]

Littlewood N, Anderson P, Artz R, Bragg O, Lunt P, Land M (2010) Peatland Biodiversity. IUCN UK Peatland Programme, Edinburgh, UK

Lucchese M, Waddington JM, Poulin M, Pouliot R, Rochefort L, Strack M (2010) Organic matter accumulation in a restored peatland: Evaluating restoration success. Ecological Engineering 36:482-488

Magurran AE (2004) Measuring biological diversity. Blackwell Science, Science, Edinburgh

Masing V, Paal J, Kuresoo A (2000) Biodiversity of Estonian Wetlands. Biodiversity in wetlands: assessment, function and conservation 1:259-279

Minayeva TY, Bragg O, Sirin AA (2017) Towards ecosystem-based restoration of peatland biodiversity. Mires and Peat 19:1-36 
Moreno-Mateos D, Power ME, Comín FA, Yockteng R (2012) Structural and functional loss in restored wetland ecosystems. PLOS Biology 10:1-8

Newey S, Mustin K, Bryce R, Fielding D, Redpath S, Bunnefeld N, Daniel B, Irvine RJ (2016)

Impact of management on avian communities in the Scottish Highlands. PloS One 11:1-15

Noreika N, Kotiaho JS, Penttinen J, Punttila P, Vuori A, Pajunen T, Autio O, Loukola O, Kotze J (2015) Rapid recovery of invertebrate communities after ecological restoration of boreal mires. Restoration Ecology 23:566-579

Oksanen J, Blanchet FG, Friendly M, Kindt R, Legendre P, McGlinn D, Minchin PR, O'Hara RP, Simpson GL, Solymos P, Stevens MHH, Szoecs E, Wagner H (2013) Package 'vegan'. Community Ecology Package 2:1-295

Parish F, Sirin A, Charman D, Joosten H, Minayeva T, Silvius M, Stringer L (2008) Assessment on peatlands, biodiversity and climate change: main report. Global Environment Centre, Kuala Lumpur and Wetlands International, Wageningen

Pearce-Higgins JW (2010) Using diet to assess the sensitivity of northern and upland birds to climate change. Climate Research 45:119-130

Pearce-Higgins JW (2011) Modelling conservation management options for a southern range-margin population of Golden Plover Pluvialis apricaria vulnerable to climate change. Ibis 153:345-356 
Penttinen J (2015) Boreal Peatland LIFE - Final Report. Metsähallitus, Vantaa, Finland

Pinheiro J, Bates D, DebRoy S, Sarkar D, R Core Team (2019) nlme: Linear and Nonlinear Mixed

Effects Models. R package version 3.1-140.

https://CRAN.R-project.org/package=nlme (accessed 8 April 2019)

R Development Core Team (2017) R: A language and environment for statistical computing. R Foundation for Statistical Computing, Wien

Rajasärkkä A (2013) Soiden ennallistaminen ja linnusto. Pages 99-101 In: Aapala K, Similä M, PenttinenJ (eds) Handbook for the restoration of drained peatlands. Nature Protection Publications of Metsähallitus, Series B 188, Metsähallitus, Vantaa, Finland [in Finnish with English abstract] https://julkaisut.metsa.fi/assets/pdf/lp/Bsarja/b188-1.pdf

Rehm EM, Baldassarre GA (2007) Temporal variation in detection of marsh birds during broadcast of conspecific calls. Journal of Field Ornithology 78:56-63

Rochefort L, Isselin-Nondedeu F, Boudreau S, Poulin M (2013) Comparing survey methods for monitoring vegetation change through time in a restored peatland. Wetlands Ecology and Management 21:71-85

Rochefort L, Quinty F, Campeau S, Johnson K, MaltererT (2003) North American approach to the restoration of Sphagnum dominated peatlands. Wetlands Ecology and Management 11:3-20 
Sanderson FJ, Donald PF, Pain DJ, Burfield IJ, van Bommel FPJ (2006) Long-term population declines in AfroPalearctic migrant birds. Biological Conservation 131:93-105

Saunders DA, Hobbs RJ, Margules CR (1991) Biological consequences of ecosystem fragmentation: a review.

Conservation Biology 5:18-32

Shantz MA, Price JS (2006) Hydrological changes foll owing restoration of the Bois-des-Bel Peatland, Quebec, 1999-2002. Journal of Hydrology 331:543-553

Slagsvold T (1977) Bird song activity in relation to breeding cycle, spring weather, and environmental phenology. Ornis Scandinavica 8:197-222

Society for Ecological Restoration International Science \& Policy Working Group (2004) The SER International Primer on Ecological Restoration. Society for Ecological Restoration International, Tucson

Tahvanainen T, Sallantaus T, Heikkilä R, Tolonen K (2002) Spatial variation of mire surface water chemistry and vegetation in northeastern Finland. Annales Botanici Fennici 39:235-251

Tiainen J, Rajasärkkä A, Mikkola-Roos M, Below A, Hario M, Lehikoinen A, LehikoinenE, Lehtiniemi T, Valkama J, Väisänen RA (2010) Suolinnuston uhanalaisuus suomessa 2010. Suomen Ympäristökeskus [in Finnish] 
UNEP, CBD, COP (2010) The Strategic Plan for Biodiversity 2011-2020 and the Aichi Biodiversity Targets: Living in Harmony with Nature. UNEP/CBD/COP/DEC/X/2. Decision Adopted by the Conference of the Partiesto the Convention on Biological Diversity at Its Tenth Meeting, Nagoya

UNGA (2019) United Nations Decade on Ecosystem Restoration (2021-2030) A/RES/73/284. United Nations General Assembly, New York

Vasander H, Tuittila ES, Lode E, Lundin L, Ilometsä M, Sallantaus T, Heikkilä R, Pitkänen M-L, Laine J (2003)

Status and restoration of peatlands in northern Europe. Wetlands Ecology and Management 11:51-63

Väisänen RA, Lammi E, Koskimies P (1998) Distribution, Numbers and Population Changes of Finnish Breeding Birds. Otava, Helsinki, Finland

Väisänen RA, Rauhala P (1983) Succession of land bird communities on large areas of peatland drained for forestry. Annales Zoologici Fennici 20:115-127

Whitehouse MJ, Harrison NM, Mackenzie J, Hinsley SA (2013) Preferred habitat of breeding birds may be compromised by climate change: unexpected effects of an exceptionally cold, wet spring. PLoS One 8: 1-13

Wilson JD, Anderson R, BaileyS, Chetcuti J, Cowie NR, Hancock MH, Quine CP, Russell N, Stephen L, Thompson DBA (2013) Modelling edge effects of mature forest plantations on peatland waders informs landscape-scale conservation. Journal of Applied Ecology 51:204-213 
Wortley L, Hero JM, Howes M (2013) Evaluating ecological restoration success: A review of the literature.

Restoration Ecology 21:537-543

Yu Z, Beilman DW, Frolking S, MacDonald GM, Roulet NT, Camill P, Charman DJ (2011) Peatlands and their role in the global carbon cycle. Eos, Transactions American Geophysical Union 92:97-98 
Table 1 All study sites include pristine (P) and restored (R) parts ('Treat'). The coordinates of the pristine and restored parts (ETRS-TM35FIN), and the restoration year are shown. The sampling years and the size of the census area are equal in pristine and restored parts.

\begin{tabular}{|c|c|c|c|c|c|c|c|c|c|c|c|c|}
\hline \multirow[b]{2}{*}{ ID } & \multirow[b]{2}{*}{ Treat } & \multirow[b]{2}{*}{ Name } & \multirow[b]{2}{*}{$\mathrm{N}$} & \multirow[b]{2}{*}{$E$} & \multirow[b]{2}{*}{ Restoration year } & \multirow[b]{2}{*}{2010} & \multicolumn{3}{|c|}{ Sampling years } & \multirow[b]{2}{*}{2014} & \multirow[b]{2}{*}{2018} & \multirow[b]{2}{*}{ Size (ha) } \\
\hline & & & & & & & 2011 & 2012 & 2013 & & & \\
\hline 1 & $P$ & Pohjaskeidas & 6882386.8 & 229483.2 & & & & & & & & \\
\hline & & & & & & $x$ & & & $x$ & $x$ & $x$ & 12.9 \\
\hline 1 & $\mathrm{R}$ & Pohjaskeidas & 6881479.2 & 228787.9 & 2012 & & & & & & & \\
\hline 2 & $P$ & Rojonkeidas & 6881930.2 & 238401.1 & & & & & & & & \\
\hline & & & & & & $x$ & & & $x$ & $x$ & $x$ & 19.9 \\
\hline 2 & $\mathrm{R}$ & Haapakeidas & 6881235.7 & 237295.5 & 2012 & & & & & & & \\
\hline 3 & $\mathrm{P}$ & Eenokinneva & 6902177.0 & 249876.0 & & & & & & & & \\
\hline & & & & & & $x$ & & & $x$ & $x$ & $x$ & 23.3 \\
\hline 3 & $\mathrm{R}$ & Lauhanvuori & 6902667.9 & 247568.2 & 2012 & & & & & & & \\
\hline 4 & $\mathrm{P}$ & Pirjatanneva & 6926300.9 & 311704.3 & & & & & & & & \\
\hline & & & & & & $x$ & $x$ & $x$ & $x$ & $x$ & $x$ & 13.8 \\
\hline 4 & $\mathrm{R}$ & Pirjatanneva & 6927889.1 & 312001.0 & 2010 & & & & & & & \\
\hline 5 & $P$ & Riihineva & 6970826.9 & 422253.0 & & & & & & & & \\
\hline & & & & & & $x$ & & $x$ & $x$ & $x$ & $x$ & 9.8 \\
\hline 5 & $\mathrm{R}$ & Riihineva & 6970572.2 & 422814.5 & 2011 & & & & & & & \\
\hline 6 & $\mathrm{P}$ & Pohjoisneva & 6997691.6 & 363305,4 & & $x$ & & & & & $x$ & 19.5 \\
\hline
\end{tabular}

This article is protected by copyright. All rights reserved. 


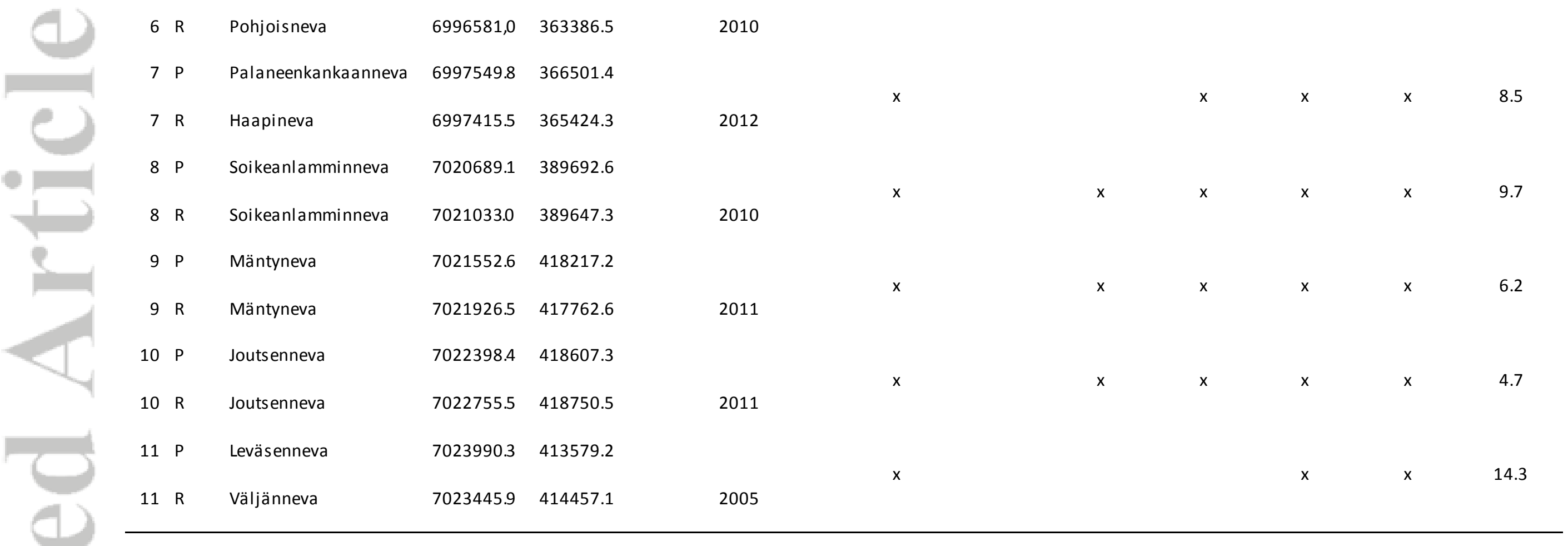




\section{FIGURE LEGENDS}

Fig. 1 Map of the study sites, including restored and pristine parts $(n=11)$.

Fig. 2 Picture from a restored part of a study site (A) and a pristine part of a study site (B).

Fig. 3 Number of species $(a, b, c)$ and number of territories $(d, e, f)$ of all species $(a, d)$, peatland specialistspecies $(b, e)$ and non-specialists $(c, f)$ in pristine and restored parts of the study sites $(n=11)$. The lines are fitted general linear models.

Fig. 4 A non-metric multidimensional scaling plot describing the bird community in drained (black symbols) and pristine (open symbols) before (circles) and after (triangles) restoration using the Bray-Curtis dissimilarity index ( $n=10)$. PcoA 1 and PcoA 2 are principal component axes 1 and 2 . The legend for each group (pristine parts, sampling year 2010; pristine parts, sampling year 2018; drained parts, sampling year 2010; restored parts, sampling year 2018) is located in the group centroid. 
Fig. 1

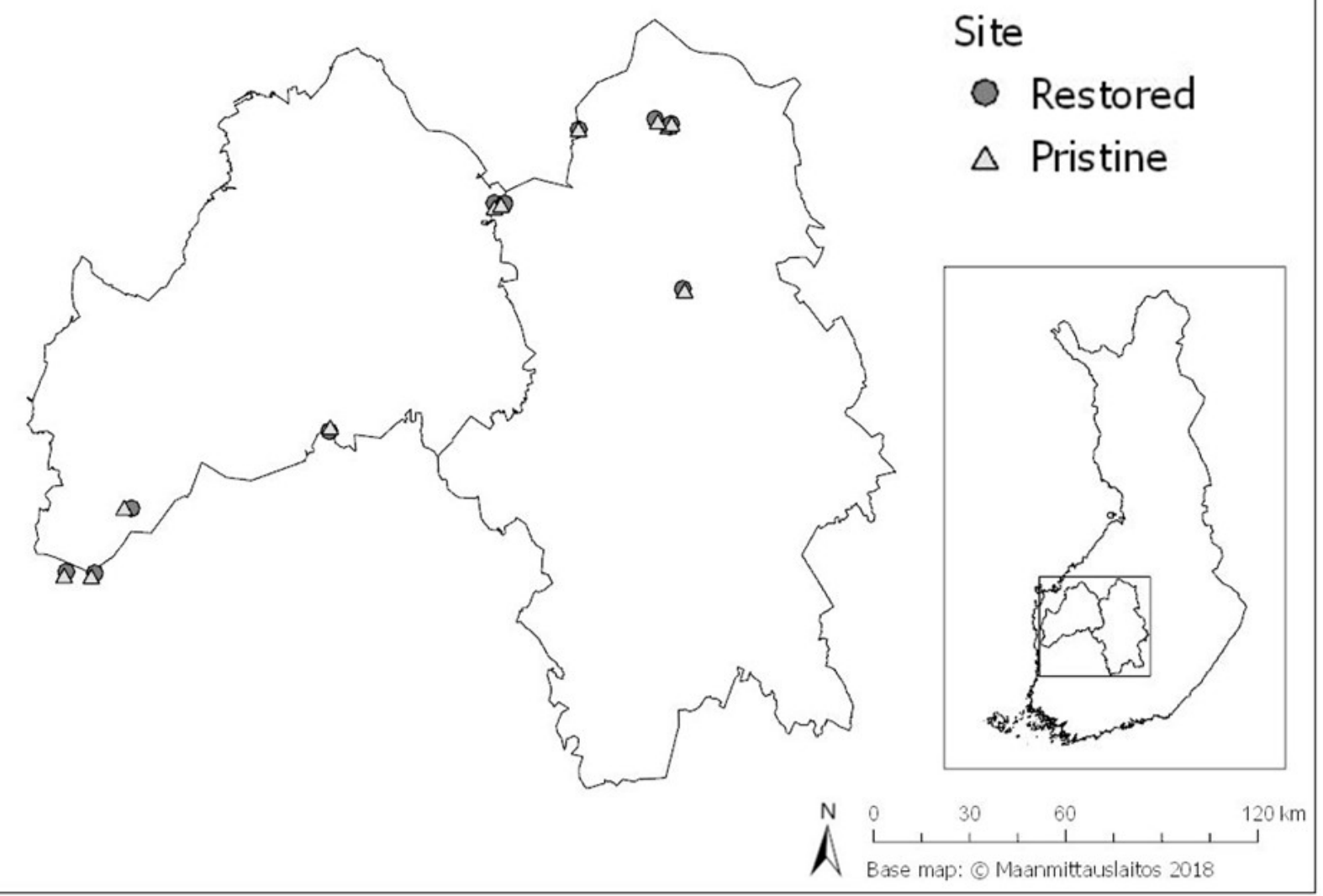


Fig. 2

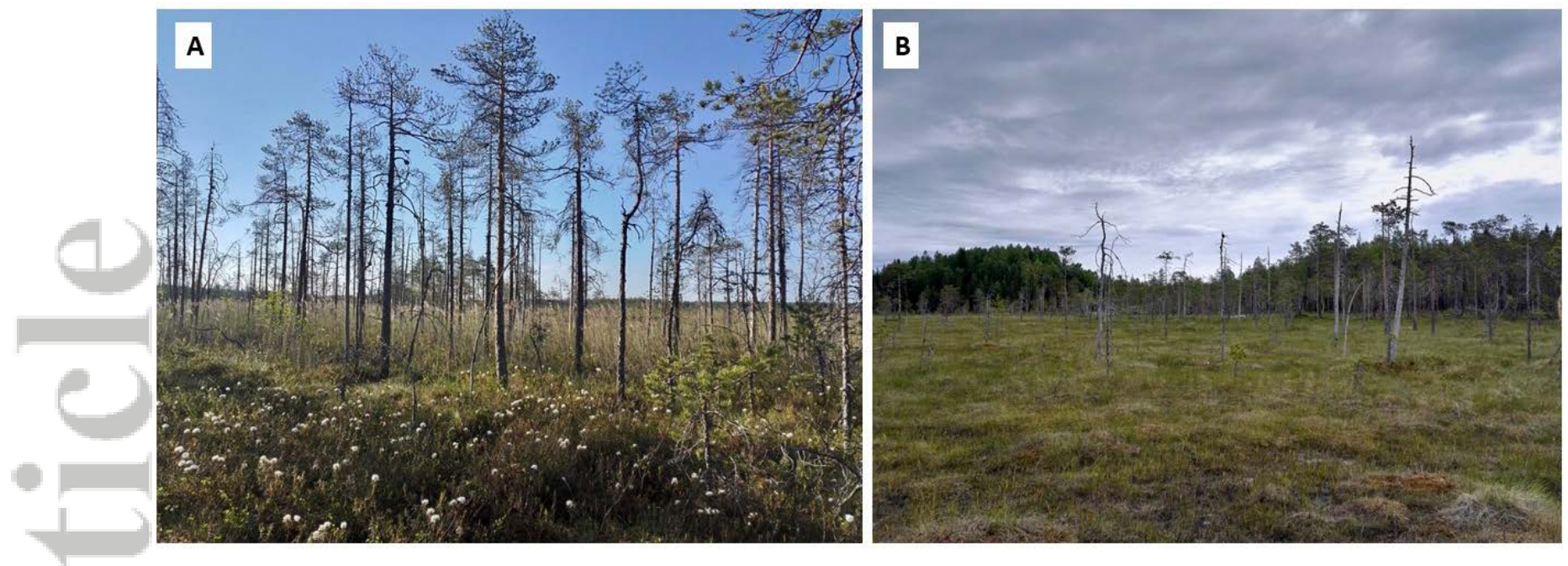

This article is protected by copyright. All rights reserved. 
Fig. 3

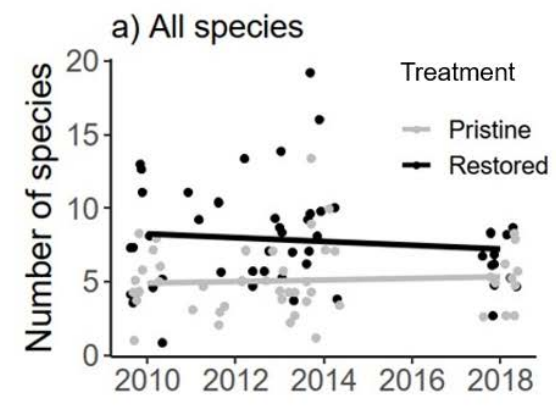
b) Peatland specialists

c) Non-specialist species
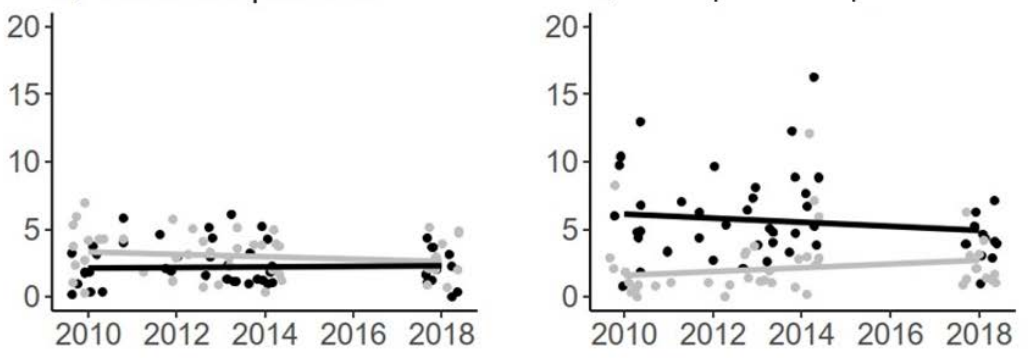

d) All species

e) Peatland specialists
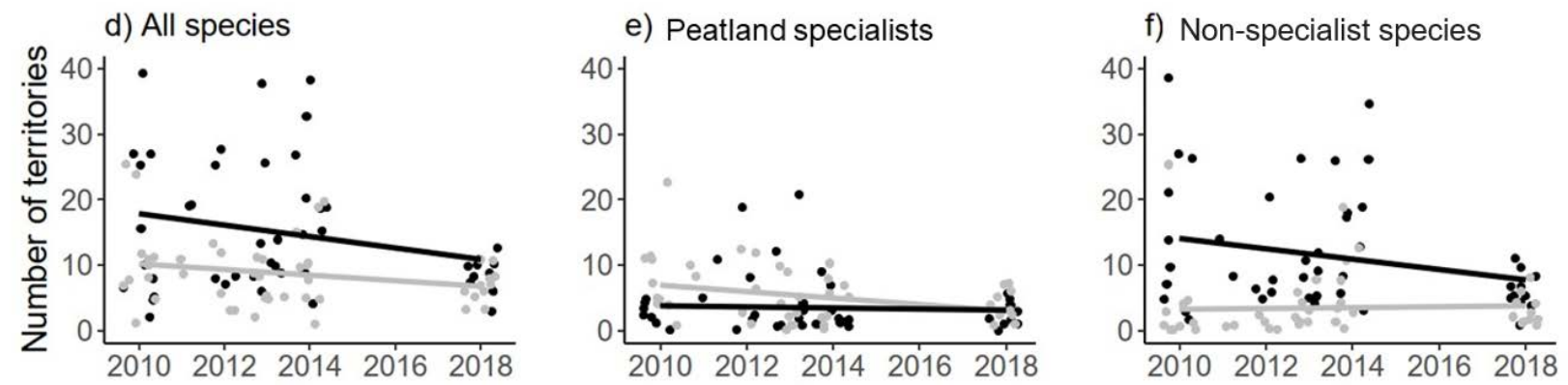
Fig. 4

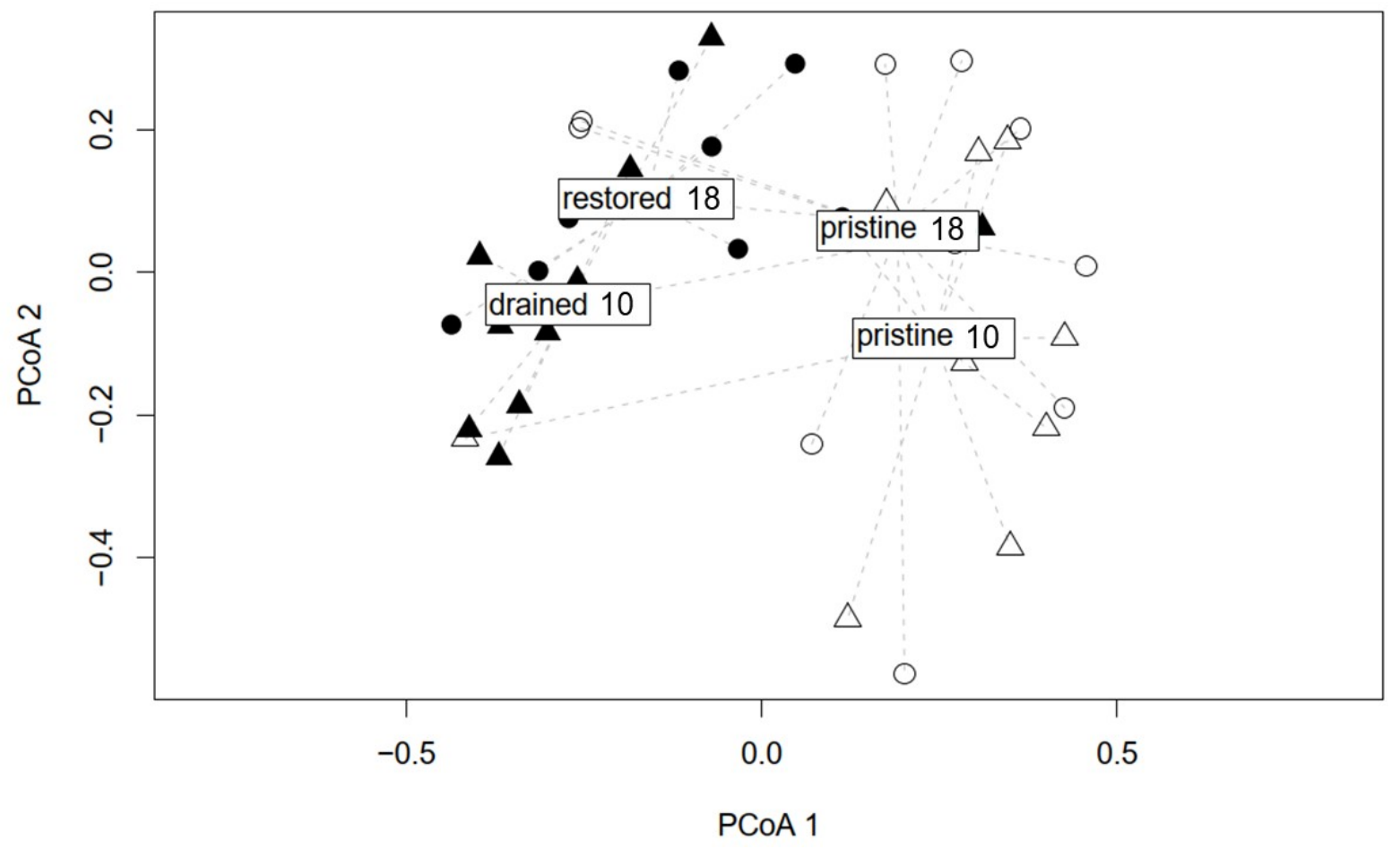

This article is protected by copyright. All rights reserved. 